\title{
Eggshell Utilisation as an Adsorbent for Treatability of Heavy Metals in Paint Wastewater
}

\author{
Adeniyi Michael Aderemi ${ }^{1,+} \cdot$ Samuel Ayoyemi Amoran ${ }^{2} \cdot$ Ahmed Kayode Aluko $^{3}$. \\ Richard Ojo Elesho' ${ }^{1}$ Oluwakemi Adewonuola Majekodunmi ${ }^{3}$ \\ ${ }^{1}$ Agricultural Technology Department, Federal College of Forestry \\ ${ }^{2}$ National Horticultural Research Institute of Nigeria \\ ${ }^{3}$ Horticulture and Landscape Technology Department, Federal College of Forestry
}

(Received April 12, 2021; Revised June 1, 2021; Accepted June 2, 2021)

\begin{abstract}
The consumption of eggs to human being and food industry is important as one of the good protein sources in life. Thus abundant of eggshells is produced as daily waste.

Objective : This study utilized eggshell as an adsorbent for diminution of heavy metal ions (manganese, zinc and iron) in paint wastewater.

Methods: The effects of adsorbent dosage $(5 \mathrm{~g} / \mathrm{l}-20 \mathrm{~g} / \mathrm{l})$ was studied in batch experiment. The $\mathrm{Mn}, \mathrm{Fe}$ and $\mathrm{Zn}$ concentrations were analyzed in replication using standard method for water and wastewater.

Results and Discussion: The adsorbent was able to have more than $50 \%$ removal efficiency at $5 \mathrm{~g}$ dosage for all the heavy metal. The optimum removal efficiency for the three heavy metal (manganese, iron and zinc) tested occurred at $15 \mathrm{~g}$ dosage of the adsorbent (71.2, 96.8 and 85.1\%).

Conclusions: The study revealed that heavy metals in wastewater from paint industries could be effectively treated with adsorbent produced from eggshell.

Keywords : Eggshell, Heavy Metals, Waste Water, Concentration, Paint
\end{abstract}




\section{Introduction}

Almost all the freshwater bodies are being polluted by expanding human population and in consequence, industrialization, intensive agricultural practices and discharge of massive amount of waste water etc., result in deterioration of water quality and consequently make the water harmful for human consumption. ${ }^{1)}$ Paint industries are major sources of these effluents ${ }^{2)}$, due to the nature of their operations which requires high volume of water that eventually results in high wastewater generation and altering the physical, chemical and biological constituent of the receiving water. Presence of toxic chemicals in the environment poses significant environmental hazards, as these chemicals ultimately reach and accumulate in animal and human tissues. The fact that many of such organic substances are carcinogenic and mutagenic in nature and severely effect human life cannot be neglected. Keeping these in view it is highly essential to eradicate these heavy metals from waste water before it is discharged to water courses $^{3)}$ and adsorption has been found most effective and versatile in this task. Adsorption techniques for wastewater treatment have become more popular in recent years with regard to their efficiency in the removal of pollutants, especially heavy metal ions, colour, odor and organic pollution. ${ }^{4)}$

In recent years, the need for safe and economical methods for the elimination of heavy metals from polluted waters has necessitated research interest toward the production of low cost alternatives to commercially available activated carbon. A number of agricultural waste materials have been investigated through adsorption method with remarkable percent removal obtained. The column adsorption study was carried out by ${ }^{5}$ using locust bean husks as biosorbent to examine irrigation water treatment prior to its application in order to ensure water crop-consumer heavy metal transfer reduction to the surface level. It was reported that locust bean husks is a potentially useful material for the removal of chromium, cadmium and arsenic in mildly polluted water. The char treatability was found to be influenced by detention time, sorbate type and adsorbent dosage. Also, in another study locust beans husk char was found to have strong affinity for aluminum, manganese and nickel removal from contaminated surface water $^{5-6)}$ carried out batch studies using tartaric acid modified rice husk as adsorbent for the removal of lead and copper and reported the effects of various parameters such as $\mathrm{pH}$, initial concentration of adsorbate, particle size, temperature etc on the treatability of heavy metals in aqueous solution. It was reported that modified rice husk is a potentially useful material for the removal of copper and lead in aqueous solutions. ${ }^{7)}$ Research was carried out on the use of coconut husk char in heavy metal removal. Heavy metals sorption on $100 \mathrm{~g}$ of the char dosage was studied under five different contact times in the column experiment. Results indicated removal efficiency for chromium, cobalt, cadmium, aluminum and arsenic at 60 mins contact time were 72, 80, 86,89 and $100 \%$ respectively.

Worldwide consumption of chicken eggs is quite high, which results into availability of large amount of discarded egg wastes, particularly egg shell (ES) and egg shell membrane (ESM). Disposal of this material is always a problematic to poultry farmers and stakeholders in the food industry. ${ }^{8)}$ Many investigations have been conducted to explore usefulness of egg waste such as to increase the mineral content of compost, to deter slugs and snails, as fertilizer, as a feed for aviary bird, cement additive to increase its strength, biodiesel. ${ }^{9)}$ Recently, utilization of poultry waste in wastewater treatment has attracted much attention from researchers. So far no efforts have been made to obtain an overview of a specific adsorbent derived from poultry by-products-the eggshell waste in treating wastewater from paint industry. Thus, this study is aimed to solve the problem of poultry waste by using eggshells as a precursor for production of adsorbent and also to use the adsorbent produce to solve the problem of heavy metals in paint wastewater.

\section{Materials and methods}

Eggshells were used as the precursor material for production of adsorbent. The eggshell as received from a poultry farm in Ogbomosho, Ogbomosho North Local Government, Oyo State, were first washed with water to get rid of impurities, dried under intense sunlight for moisture reduction for one week and stored in air-tight jar at room temperature. The dried eggshells were then carbonized using a muffle furnace at a temperature of $420^{\circ} \mathrm{C}$ for a period of 120 mins. Char produced was reduced in size to enhance adsorption rate and sorted with $1.18 \mathrm{~mm}$ sieve before storage. The paint wastewater sample was collected under stringent conditions from a local paint industry at Aleshinloye Market, Ibadan South West Local Government Area of Oyo State, Nigeria. Batch study was conducted on wastewater. 5, 10, 15 and $20 \mathrm{~g}$ of adsorbents were put in $200 \mathrm{ml}$ of wastewater sample. The flask containing 
Table 1. Mean concentration of heavy metals in treated and untreated paint wastewater.

\begin{tabular}{ccccccc} 
Parameter & Untreated $(\mathrm{mg} / \mathrm{L})$ & \multicolumn{5}{c}{ Treated $(\mathrm{mg} / \mathrm{L})$} \\
& & $5 \mathrm{~g}$ & $10 \mathrm{~g}$ & $15 \mathrm{~g}$ & $20 \mathrm{~g}$ \\
Manganese & $0.139 \pm 0.215$ & $0.064 \pm 0.61$ & $0.050 \pm 0.52$ & $0.040 \pm 0.05$ & $0.050 \pm 0.015$ \\
\hline Iron & $9.654 \pm 0.614$ & $1.353 \pm 0.023$ & $0.606 \pm 0.056$ & $0.303 \pm 0.652$ & $1.094 \pm 0.05$ \\
\hline Zinc & $0.121 \pm 0.065$ & $0.040 \pm 0.644$ & $0.028 \pm 0.59$ & $0.018 \pm 0.58$ & $0.043 \pm 0.015$ \\
\hline
\end{tabular}

raw wastewater samples were shaken intermittently for 1 hour, allowing sufficient time for adsorption equilibrium and wastewater was filtered through (Whatmann No. 44) filter paper. Contaminant analysis in the treated and untreated water samples were determined according to Standard Methods for the Examination of Water and Wastewater and replicated twice to cater for possible variations.

The removal efficiency of adsorbents was calculated using: Percentage adsorbed $=(\mathrm{Ci}-\mathrm{Ce}) / \mathrm{Ci} \times 100 . \mathrm{Ci}(\mathrm{mg} / \mathrm{L})$ represents initial concentration of effluents before process of adsorption. $\mathrm{Ce}(\mathrm{mg} / \mathrm{L})$ represents residual concentration after adsorption of effluents.

\section{Results and discussion}

Table 1 and 2 showed the mean concentration of heavy metals in treated and untreated paint wastewater and the removal efficiency of eggshell adsorbent respectively. From the tables, eggshell adsorbent exhibited high removal efficiency for all the heavy metals tested though the removal efficiency varies with adsorbent dosage. The optimum removal efficiency for the three heavy metal (manganese, iron and zinc) tested occurred at $15 \mathrm{~g}$ dosage of the adsorbent (71.2, 96.8 and $85.1 \%$ ) respectively. Iron demonstrated exceptionally rapid uptake at all dosage of adsorbent when compared to other heavy metal tested. The initial concentration of manganese, iron and zinc in the wastewater was far higher than $\leq 0.3$ to $0.5 \mathrm{mg} / \mathrm{L}, \leq 0.3$ to $0.9 \mathrm{mg} / \mathrm{L}$ and $\leq 0.3$ to $0.5 \mathrm{mg} / \mathrm{L}$ respectively ${ }^{10)}$ which is the minimum permissible limit for wastewater discharge by WEPA, eggshell adsorbent was able to reduce the concentration to below permissible limit at $20 \mathrm{~g}$ dosage for 1 hour contact time. The adsorbent was able to have more than $50 \%$ removal efficiency at $5 \mathrm{~g}$ dosage for all the heavy metal. The result showed that manganese, iron and zinc have high mobility to the adsorbents surface. The general trend for experimental carbon and heavy metal studied shows adsorbent dosage influence removal efficiency throughout the period of the experiment, though the adsorbents displayed different sorption tendencies with respect to heavy
Table 2. Removal efficiency of eggshell adsorbent.

\begin{tabular}{c|c|c|c|c} 
& \multicolumn{4}{c}{ Removal efficiency \% } \\
\cline { 2 - 5 } Parameter & $5 \mathrm{~g}$ & $10 \mathrm{~g}$ & $15 \mathrm{~g}$ & $20 \mathrm{~g}$ \\
\hline Manganese & 53.9 & 64 & 71.2 & 64 \\
\hline Iron & 84.9 & 93.7 & 96.8 & 88.7 \\
\hline Zinc & 66.9 & 76.9 & 85.1 & 64.5 \\
\hline
\end{tabular}

metals. The optimum removal was achieved at $15 \mathrm{~g}$ dosage as shown in Table 2 after which there was a decline in the removal efficiency for all the heavy metal treated. The result corroborated the earlier study by ${ }^{11)}$ that eggshell is an effective material in removing heavy metals of copper and zinc from aqueous solution.

\section{Conclusions}

This study has attempted to solve the problem of both solid waste in food/agricultural processing and wastewater disposal in the paint production industry by using solid waste (eggshells) as a precursor for production of adsorbent to treat heavy metals in paint wastewater. The study revealed that heavy metals in wastewater from paint industries could be effectively treated with adsorbent produced from eggshell. The optimum removal was achieved at $15 \mathrm{~g}$ dosage per $200 \mathrm{ml}$ of paint wastewater. The use of eggshell as a low cost adsorbent for treating wastewater could reduce solid waste in open dump/landfill site if properly utilizes. The removal efficiency pattern for all the heavy metals indicates the relationship among adsorbent dosage and sorbate under consideration. Further studies could be conducted to inspect the relationship between contact time, adsorbent dosage, and sorbate. Effect of activated eggshell on heavy metal removal could also be investigated.

\section{References}

1. A. M. Oloyede, O. Ogunlaja, A. Ogunlaja, Sub-chronic toxicity assessment of local textile 'adire and kampala' (tie and dye) effluents on mice (mus musculus), Res. J. Environ. Sci., 8(3), 142-148(2014). 
2. M. A. Aboulhassan, S. Souabi, A. Yaacoubi, M. Baudu, Treatment of paint manufacturing wastewater by the combination of chemical and biological processes, Int. J. Environ. Sci. Technol., 3(5), 1747-1758(2014).

3. S. J. Allen, B. Koumanova, Decolourisation of water/wastewater using adsorption (review), J. Univ. Chem. Technol. Metallurgy, 40(3), 175-192(2005).

4. M. T. Ganji, M. Khosravi, R. Rakhshaee, Biosorption of Pb, $\mathrm{Cd}, \mathrm{Cu}$ and $\mathrm{Zn}$ from the wastewater by treated azolla filiculides with $\mathrm{H}_{2} \mathrm{O}_{2} / \mathrm{MgCl}_{2}$, Int. J. Environ. Sci. Tech., 1(4), 265-271(2005).

5. A. A. Ajayi-Banji, T. Ewemoje, A. Ajimo, Efficacy of locust beans husk char in heavy metal sequestration, Environ. Res., Eng. Manag., 71(4), 5-10(2015).

6. K. K. Wong, C. K. Lee, K. S. Low, M. J. Haron, Removal of $\mathrm{Cu}$ and $\mathrm{Pb}$ by tartaric acid modified rice husk from aqueous solution, Chemosphere, 50(1), 23-28(2003).

7. A.-B. Ademola, S. Abimbola, I. Opolola, Coconut husk char biosorptivity in heavy metal diminution from contaminated surface water, J. Eng. Stud. Res., 21(4), 7-13(2015).

8. A. Mittal, M. Teotia, R. K. Soni, J. Mittal, Applications of egg shell and egg shell membrane as adsorbents: a review, J. Mol. Liq., 376-387(2016).

9. Water Environment Partnership in Asia, http://www.wepa-db.net/ policies/law/laos/standards.htm\#01, June(2013).

10. Z. Wei, C. Xu, B. Li. Application of waste eggshell as low-cost solid catalyst for biodiesel production, Bioresour. Technol., 100(11), 2883-2885(2009).

11. S. Badrealam, F. S. Roslan, Z. Dollah, A. A. A. Bakar, R. Handan, Exploring the eggshell from household waste as alternative adsorbent for heavy metal removal from wastewater, in Proceedings of AIP Conference 2020, AIP Publishing, pp. 1-7(2020).

\section{Declaration of Competing Interest}

The authors declare that they have no known competing financial interests or personal relationships that could have appeared to influence the work reported in this paper.

\section{Authors and Contribution Statement}

\section{Adeniyi Michael Aderemi}

Agricultural Technology Department, Federal College of Forestry, Lecturer, Researcher, ORCID (1) 0000-0001-9615-866X: Conceptualization, Methodology, Data analysis, Writing-original draft, Project administration.

\section{Samuel Ayoyemi Amoran}

National Horticultural Research Institute of Nigeria, Researcher: Project administration, Resources.

\section{Ahmed Kayode Aluko}

Horticulture and Landscape Technology Department, Federal College of Forestry, Lecturer, Researcher: Methodology, Validation, Visualisation.

\section{Richard Ojo Elesho}

Agricultural Technology Department, Federal College of Forestry, Lecturer, Researcher: Methology, Funding acquisition, Data analysis, Writing-original draft.

\section{Oluwakemi Adewonuola Majekodunmi}

Horticulture and Landscape Technology Department, Federal College of Forestry, Lecturer, Researcher: Conceptualization, Data curation, Fund acquisition, Methodology, Project administration. 